International Journal of
BioScience and Applications

\title{
Study on the Application of Natural Substances to Cosmeics
}

\author{
Hye-Jin Kwon ${ }^{1}$ \\ ${ }^{1}$ Department of Chemical Engineering, University of Soongsil, Seoul, CO 06978, Korea
}

\begin{abstract}
Background/Objectives: This study was conducted on the application of natural cosmetics using Stachys sieboldii Miq. Roots and their Antioxidant, anti-aging and whitening. Methods/Statistical analysis: The DPPH radical scavenging activity of Stachys sieboldii Miq. root extract was increased in a concentration-dependent manner in an antioxidant activity test. Its ABTs radical scavenging activity was $94.32 \pm 0.12 \%$ at a concentration of $1000 \mu \mathrm{g} / \mathrm{mL}$, and its collagenase inhibitory activity was $39.4 \pm 2.52 \%$ at the same level of concentration in an anti-aging activity test. Findings: These findings suggest that Stachys sieboldii Miq. roots have potential antioxidant, whitening and anti-aging effects. Improvements/Applications: It is deemed that Stachys sieboldii Miq. root extract can be effectively used in the development of new functional cosmetic ingredients.
\end{abstract}

\section{Index Terms}

Stachys sieboldii Miq. root extract, antioxidant, anti-aging, whitening, functional cosmetic

\footnotetext{
Corresponding author : H. J. Kwon

kwonhj0070@ssu.ac.kr

- Manuscript received July 15, 2020.

- Revised August 10, 2020 ; Accepted September 2, 2020.

- Date of publication September 30, 2020.

(c) The Academic Society of Convergence Science Inc.

2619-8363 () 2020 IJBSA. Personal use is permitted, but republication/redistribution requires IJBSA permission.
} 


\section{INTRODUCTION}

Unlike synthetic chemicals, physiologically active substances of natural products have relatively less toxicity issues on the human body, and above all, since natural products have the advantage of exhibiting various pharmacological activities at one time, those with proven pharmacological efficacy are used as ingredients for various foods, drugs, and cosmetics [1,2]. In general, exploring medicinal plants that have been traditionally used can be a very important step as a way to discover functional materials with excellent pharmacological activities and little side effects. The pharmacological effects of medicinal plants, which have been used empirically in the private sector, are often generally described as antioxidant effects. It has been reported that the antioxidant effects of medicinal plants are better than fruits and vegetables consumed in daily life $[3,4]$. Stachys sieboldii Miq. (Stachys sieboldii Miq.) is a perennial plant of the Lamiaceae family, and is known as a traditional health-functional vegetable in China [5]. It is a yearly herb and known to grow lush oval leaves in summer and 3 to 6-centimeter roots underground in winter, with an overall shape of a whelk, or Cordyceps militaris [6]. Stachys sieboldii Miq. extract has been reported to relieve dementia symptoms and maintain normal function of the brain in the animal brain tissue, while inhibiting damage to the brain tissue caused by free radicals [7-9]. In addition, Stachys sieboldii Miq. extract has been known for its antioxidant activities such as inhibiting the formation of lipid peroxides and scavenging nitrite. Recently in Korea, Stachys sieboldii Miq. has attracted attention for its excellent effect in preventing dementia, which leads to increasing cultivation areas for the production of this herb [10]. Therefore, this study aimed at providing basic data on the potential use of Stachys sieboldii Miq. as a functional ingredient by examining the effects of its root extract gained by extraction with $80 \%$ ethanol solvent on antioxidant activity, brightening, and antiaging.

\section{Methods}

\section{A. Material preparation}

After adding $500 \mathrm{ml}$ of $80 \%$ ethanol to $50 \mathrm{~g}$ of Stachys sieboldii Miq. and extracting it under reflux for three hours, the filtrate was concentrated under reduced pressure with a rotary vacuum evaporator. The concentrated solution was freeze-dried with a freeze dryer, to obtain $31.6 \mathrm{~g}$ (yield: $63.2 \%$ ) of powder. It was stored in a cryogenic freezer $\left(-80^{\circ} \mathrm{C}\right)$ and diluted in distilled water to the concentration required for the test.

\section{B. DPPH radical scavenging activity measurement}

DPPH radical scavenging activity was measured by employing the Blois method. The sample concentration levels of $1 \mu \mathrm{g} / \mathrm{mL}, 10 \mu \mathrm{g} / \mathrm{mL}, 100$ $\mu \mathrm{g} / \mathrm{mL}$, and $1000 \mu \mathrm{g} / \mathrm{mL}$ were equally applied to all tests. $150 \mu \mathrm{l}$ of $0.2 \mathrm{mM}$ DPPH solution was prepared, mixed, and reacted at $37^{\circ} \mathrm{C}$ for 30 minutes. The absorbance was measured at $515 \mathrm{~nm}$.

\section{ABTs cation radical scavenging activity assay}

The measurement of antioxidant activity using ABTS radicals was performed by using the ABTS cation decolorization assay method. First, $7 \mathrm{mM} \mathrm{2,2-}$ zino-bis-(3-ethyl-benthiazoline-6-sulfonic acid) and $2.45 \mathrm{mM}$ potassium persulfate were mixed and left at room temperature for 24 hours to form ABTS+. It was then diluted with ethanol, and $100 \mu \mathrm{L}$ of the sample was added to $100 \mu \mathrm{L}$ of ABTS, and the absorbance was measured at $700 \mathrm{~nm}$.

\section{Tyrosinase inhibitory activity measurement}

Tyrosinase inhibitory activity was measured in accordance with the method of Yagi. In the reaction zone, $40 \mu \mathrm{L}$ of $200 \mathrm{U} / \mathrm{mL}$ mushroom tyrosinase was added to a mixture of $40 \mu \mathrm{L}$ of a substrate with 10 $\mathrm{mM}$ L-DOPA dissolved in $80 \mu \mathrm{L}$ of $67 \mathrm{mM}$ sodium phosphate buffer ( $\mathrm{pH}$ 6.8) and $40 \mu \mathrm{L}$ of the sample solution. The mixture was reacted at $37^{\circ} \mathrm{C}$ for 10 minutes and the DOPA chrome generated in it was measured at $492 \mathrm{~nm}$. The tyrosinase inhibitory activity was expressed as the rate of decrease in the absorbance of the sample solution-added and noadded groups.

\section{E. Elastase inhibitory activity measurement}

Elastase inhibitory activity was measured in accordance with the method of Cannell. Using Nsuccinyl- (L-Ala)3-p-nitroanilide (Sigma, U.S.A.) as a substrate, the amount of p-nitroanilide produced from the substrate was measured at $445 \mathrm{~nm}$ for 30 minutes at $37^{\circ} \mathrm{C}$. More specifically, each test solution was prepared to a certain concentration and then taken into a 96 -well plate by $40 \mu \mathrm{L}$, and $40 \mu \mathrm{L}$ of porcine pancreas elastase $(2.5 \mathrm{U} / \mathrm{mL})$ (Sigma, U.S.A.) dissolved in $50 \mathrm{mM}$ tris- $\mathrm{HCl}$ buffer ( $\mathrm{pH} 8.6)$ was applied to it. Thereafter, $80 \mu \mathrm{L}$ of N-succinyl(L-Ala)3-p-nitroanilide $(0.5 \mathrm{mg} / \mathrm{mL})$ dissolved in 50 $\mathrm{mM}$ tris- $\mathrm{HCl}$ buffer ( $\mathrm{pH}$ 8.6) was added as a substrate to react for 30 minutes. The amount of $p$ nitroanilide produced from the substrate was then measured at $445 \mathrm{~nm}$. The elastase inhibitory activity was expressed as the rate of decrease in the absorbance of the sample solution-added and noadded groups. 


\section{F. Collagenase inhibitory activity measurement}

Collagenase inhibitory activity was measured in accordance with the method of Wünsch $\mathrm{E}$ and Heindrich HG. In the reaction zone, $75 \mu \mathrm{L}$ of 0.2 $\mathrm{mg} / \mathrm{mL}$ collagenase (Sigma, U.S.A.) was added to a mixture of $75 \mu \mathrm{L}$ of a substrate obtained by dissolving $\quad 0.3 \quad \mathrm{mg} / \mathrm{mL}$ of 4 phenylazobenzyloxycarbonyl-Pro-Leu-Gly-Pro-DArg (Sigma, U.S.A.) in $0.1 \mathrm{M}$ tris- $\mathrm{HCl}$ buffer (pH 7.5) with $4 \mathrm{mM} \mathrm{CaCl} 2$ added and $50 \mu \mathrm{L}$ of the sample solution. It was then left for 20 minutes at room temperature, and by the addition of $250 \mu \mathrm{L}$ of $6 \%$ citric acid, the reaction was halted. Thereafter, by adding $1.5 \mathrm{~mL}$ of ethyl acetate, absorbance was measured at $320 \mathrm{~nm}$. The collagenase inhibitory activity was expressed as the rate of decrease in the absorbance of the sample solution-added and noadded groups.

\section{RESULTS AND DISCUSSION}

\section{A. DPPH radical scavenging activity}

This factor is widely used to determine the free radical scavenging ability of natural extracts containing phenolic compounds. The electron donating ability of the ethanol extract of Stachys sieboldii Miq. root was $39.47 \%$ at $1000 \mu \mathrm{g} / \mathrm{mL}$, which indicates its excellent antioxidant activity (Fig. 1)

\section{B. ABTs cation radical scavenging activity}

The ABTs radical scavenging activity at each concentration level was measured and charted in Fig. 2. As seen in Fig. 1, ABTs radical scavenging activity tended to increase in a concentrationdependent manner, and a high activity of about $94.32 \pm 0.12 \%$ was shown at a concentration of 1,000 $\mu \mathrm{g} / \mathrm{mL}$, which is similar to that observed in the control solution, $0.1 \%$ BHT $(108.19 \pm 6.51 \%)$. The ABTs radical scavenging activity in the extract were $0.00 \pm 0.31 \%, \quad 1.97 \pm 0.49 \%, \quad 25.27 \pm 1.61 \%, \quad$ and $94.32 \pm 0.12 \%$, respectively. Overall, when the concentration of the extract is $1000 \mu \mathrm{g} / \mathrm{mL}$ or higher, $90 \%$ or higher levels of ABTs scavenging activity were observed, which demonstrates a high scavenging activity. In general, differences in the levels of DPPH and ABTs radical scavenging activity can be attributed to differences in radical removal mechanism, degrees of substrate binding, and compositions of polar and non-polar substances in the extract according to the types of antioxidants [11].

\section{Tyrosinase inhibitory activity}

Tyrosinase, as a type of polyphenol oxidase, is an

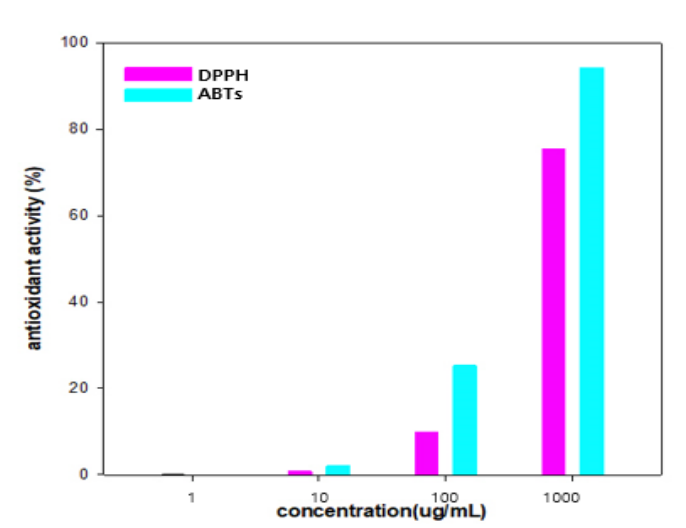

Fig. 1. Antioxidant activity of Stachys sieboldii Miq. Root extracts

enzyme containing $\mathrm{Cu} 2+$ and involved in the biosynthesis of the melanin pigment. Melanin increases the skin's resistance to UV rays, dryness, and extreme temperatures, but excessive melanin production causes pigmentation such as spots, freckles, and age spots on the skin and accelerates skin aging. Therefore, tyrosinase inhibitory activity is one of the very important factors involved in the browning of organisms [12]. As shown in Table 1, the tyrosinase inhibitory activity of the extract increased according to concentration levels, measured as $20.70 \pm 0.47 \%$ at a concentration of 1000 $\mu \mathrm{g} / \mathrm{mL}$.

Table. 1. Tyrosinase inhibitory activity of Stachys sieboldii Miq. Root extracts

\begin{tabular}{cc}
\hline \hline Concentration & $\begin{array}{c}\text { Tyrosinase inhibitory } \\
\text { activity }(\%)\end{array}$ \\
\hline 1 & $0.62 \pm 2.04$ \\
10 & $3.36 \pm 0.14$ \\
100 & $11.16 \pm 1.53$ \\
1000 & $20.70 \pm 0.47$ \\
\hline
\end{tabular}

\section{Elastase inhibitory activity}

The extract inhibited elastase in a concentrationdependent manner at concentrations of $1 \mu \mathrm{g} / \mathrm{mL}, 10$ $\mu \mathrm{g} / \mathrm{mL}, 100 \mu \mathrm{g} / \mathrm{mL}$, and $1000 \mu \mathrm{g} / \mathrm{mL}$, respectively, but the degree of activity was slightly insignificant (Fig. 2). The elastase inhibitory activity was $0.89 \pm 3.30 \%, \quad 2.09 \pm 3.51 \%, \quad 11.98 \pm 3.29 \%$, and $28.11 \pm 2.53 \%$, respectively.

\section{E. Collagenase inhibitory activity}

Collagen is ECM fibrillar molecules that make up the dermis and plays a role in maintaining the firmness of the skin, divided into five types (I, II, III, 
IV, V). The decrease in collagen is due to a decrease in the synthesis ability of skin fibroblasts or an increase in resolution by collagenase. Collagen decreases not only by aging but also by photoaging caused by UV irradiation, which is known to be closely related to the formation of wrinkles on the skin[13-15]. In the test, collagenase inhibitory activity was measured as $1.61 \pm 3.06 \%, 4.29 \pm 1.03 \%$, $18.08 \pm 4.73 \%$, and $39.47 \pm 2.52 \%$ (Fig. 3). The antiaging effect of Stachys sieboldii Miq. roots is thought to play a role in inhibiting the generation of ROS caused by photoaging due to ultraviolet rays and suppressing the formation of wrinkles by scavenging the generated ROS.

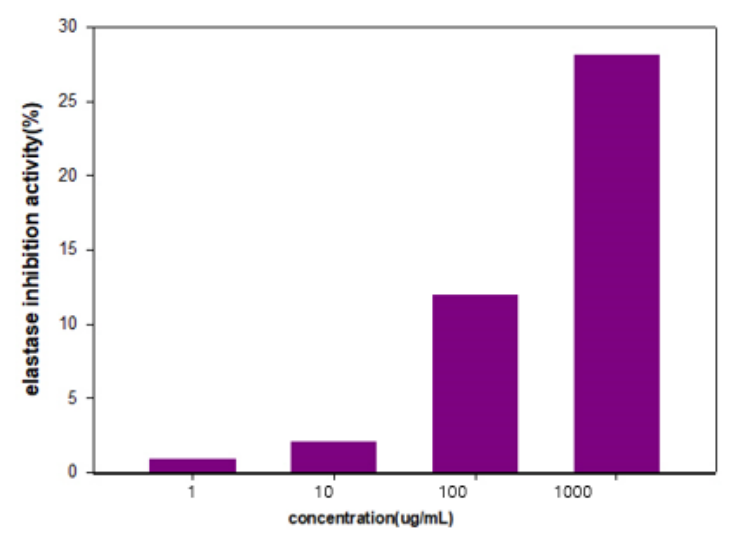

Fig. 2. Elastase inhibitory activity of Stachys sieboldii Miq. Root extract.

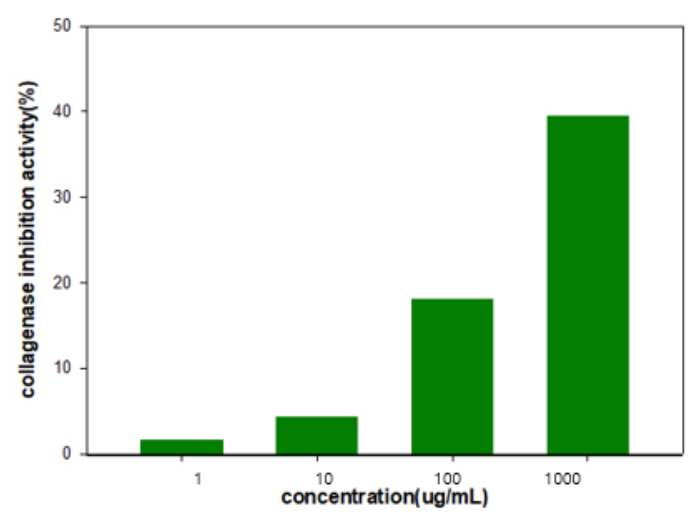

Fig. 3. Collagenase inhibitory activity of Stachys sieboldii Miq. Root extract.

\section{Conclusion}

This study was conducted to find ways to use Stachys sieboldii Miq. roots rich in choline and phenylethanoids as functional cosmetic ingredients in the future by examining their antioxidant, brightening, and anti-aging effects. The study results can be summarized as follows. The Stachys sieboldii
Miq. root extract showed a DPPH radical scavenging activity of $39.47 \%$ at a concentration of $1000 \mu \mathrm{g} / \mathrm{mL}$, and its ABTs radical scavenging activity was $94.32 \pm 0.12 \%$ at a concentration of $1000 \mu \mathrm{g} / \mathrm{mL}$. This indicates that it possesses an excellent antioxidant activity. In the anti-aging effect test, it showed a somewhat insignificant level of elastase inhibitory activity, but its collagenase inhibitory activity was measured as $39.47 \%$ at a concentration of 1000 $\mu \mathrm{g} / \mathrm{mL}$. Overall, it is deemed that Stachys sieboldii Miq. root extract can be effectively used in the development of new functional cosmetic ingredients.

\section{REFERENCES}

[1] Hwang, S., Park S., \& Kim J. (2013). Component analysis and antioxidant activity of Oenanthe javanica extracts. Korean Journal of Food Science and Technology, 45(2), 227-234. DOI: 10.9721/KJFST.2013.45.2.227

[2] Kwon, O., Lee, H., Kim, T., Kim, S. (2014). Antioxidant and pancreatic lipase inhibitory activities of Anemarrhena asphodeloides. Korean $J$ Food Preserv, 21(3),421-426. DOI; $10.11002 / \mathrm{kjfp} .2014 .21 .3 .421$

[3] Jang, T., Park, J. (2017). Antioxidative Activities and Whitening Effects of Ethyl Acetate Fractions from The Immature Seeds of Abeliophyllum distichum. Journal of Life Science, 27(5), 536-544. DOI:10.5352/JLS.2017.27.5.536

[4] Jiménez-Cervantes C, Martínez-Esparza M., Pérez C, Daum, N, Solano, F, García-Borrón J.C. (2001). Inhibition of melanogenesis in response to oxidative stress: transient downregulation of melanocyte differentiation markers and possible involvement of microphthalmia transcription factor. J. Cell Sci., 114(2), 2335-2379.

[5] Xu, M., Chen, Y. M., Huang, J., Fang, Y. J., Huang, W. Q., Yan, B., Lu, M. S., Pan, Z. Z. Zhang, G. X. (2016). Flavonoid intake from vegetables and fruits is inversely associated with colorectal cancer risk: a case-control study in China. Br. J. Nutr. 116(7), 12751287.

DOI: $10.1017 / \mathrm{S} 0007114516003196$

[6] Jeon, K., Park, S. (2015). Antioxidative properties of Chinese Artichoke (Stachys sieboldii Miq) added white bread. Kor. J. Culinary Res. 21(6), 120-132. DOI: $10.20878 / \mathrm{cshr} .2015 .21 .6 .010$

[7] Kim, K., Kim, N., Kim, S., Han, I., Yook, H. (2012). Study on antioxidant effects of fractional extracts from Ligularia senocephala leaves. J. Kor. Soc. Food Sci. Nutr. 41(9), 1220-1225. DOI: $10.3746 / \mathrm{jkfn} .2012 .41 .9 .1220$

[8] Feng, K., Chen, W., Sun, L., Liu, J., Zhao, Y., Li, L., Wang, Y., Zhang, W. (2015). Optimization extraction, preliminary characterization and antioxidant activity in vitro of polysaccharides from Stachys sieboldii Miq. Tubers. Elsevier, 125, 45-52. DOI: 10.1016/j.carbpol.2015.02.026

[9] Lee, J., Wu, W. and Lim, S. (2018). Effect of extracts from Stachys sieboldii Miq. on cellular reactive oxygen species and glutathione production and 
genomic DNA oxidation. Asian Pacific J. Tropical Biomed. 8(10), 485-489.

DOI: 10.4103/2221-1691.244139

[10] Kokhdan, E. P., Sadeghi, H., Ghafoori, H., Sadeghi, H., Danaei, N., Javadian, H. and Aghamaali, M. R (2018). Cytotoxic effect of methanolic extract, alkaloid and terpenoid fractions of Stachys pilifera against HT-29 cell line. Res. Pharm. Sci. 13(5), 404412.

DOI: $10.4103 / 1735-5362.236833$

[11] Toth, T., Kovarovic, J., Bystricka, J., Vollmannova, A., Musilova, J., Lenkova, M. (2018). The content of polyphenols and antioxidant activity in leaves and flowers of wild galic (Allimursinum L.). Acta Alimentaria, 47(2), 1-10.

DOI: 10.1556/066.2018.47.2.15

[12] Sinaga, S.M., Iksen, I., G. Haro, G., Wardhany, S. (2017). Evaluation of total phenolic, flavonoid content, antioxidant and in vitro antilithogenesis activities of chives leaf (Allium schoenoprasum L. Rasayan Journal of Chemistry, 11(4), 1604-1608.

DOI: 10.31788/RJC.2018.1144067

[13] Nugara, R.N., Inafuku, M., Iwasaki, H., Oku, H. (2014). Partially purified Peucedanum japonicum Thunb extracts exert anti-obesity effects in vitro. Nutrition, 30(5), 575-583.

DOI: 10.1016/j.nut.2013.09.017

[14] Xie, Y., Xiao, M., Ni, Y., Jiang, S., Feng, G., Sang, S., Du, G. (2018). Alpinia oxyphylla Miq. extract prevents diabetes in mice by modulating gut microbiota, J Diabete Res, 2018, 1-10. DOI: $10.1155 / 2018 / 4230590$

[15] M. Hu, M., Yu, Z., Wang, J., Fan, W., Liu, Y., Li, J., $\mathrm{Wu}$, C. (2017). Traditional uses, origins, chemistry and pharmacology of Bombyx batryticatus: a review, Molecules, 22(10), 1779.

DOI: $10.3390 /$ molecules22101779 